\title{
Pengaruh Current Ratio, Net Profit Margin Dan Price Earning Ratio Terhadap Return Saham Pada Perusahaan Subsektor Otomotif dan Komponen yang Terdaftar Di Bursa Efek Indonesia (BEI)
}

\author{
Andri Adidi', Reva Maria Valianti ${ }^{2}$ \\ ${ }^{1}$ Akuntansi, FE Universitas PGRI Palembang \\ ${ }^{2}$ Akuntansi, FE Universitas PGRI Palembang, revavalianti@univpgri-palembang.ac.id
}

\begin{abstract}
This study aims to determine the effect of current ratio, net profit margin and price earning share on stock returns of the automotive and component sub-sector companies. The sample was selected as many as 8 companies from 12 companies listed on the IDX. The data analysis technique uses a multiple linear regression analysis model after going through the testing phase of the model which is the classic assumption which consists of data normality test, autocorrelation test, multicollinearity test and heteroscedasticity test. Further testing of the $F$ test hypothesis and t test is carried out. The test results show that the current ratio, net profit margin and price earning share obtained a value of 0.097 which means that simultaneously there is no significant effect on the independent variable on the dependent variable. The results of the $t$ test for the current ratio variable obtained a value of $0.962>$ 0.05 , the variable net profit margin obtained a value of $0.223>0.05$ means that $C R$ and NPM have no significant effect on stock returns. Price earning share variable obtained value of $0.044>0.05$ means that there is a significant effect on stock returns.
\end{abstract}

Keywords : Current Ratio, Net Profit Margin, Price Earning Ratio and Stock Return

\begin{abstract}
ABSTRAK
Penelitian ini bertujuan untuk mengetahui pengaruh current ratio, net profit margin dan price earning share terhadap pengembalian saham perusahaan subsektor notomotif dan komponen. Sampel terpilih sebanyak 8 perusahaan dari 12 perusahaan yang terdaftar di BEI. Teknik analisis data menggunakan model analisis regresi linear berganda setelah melalui tahap pengujian model yaitu asumsi klasik yang terdiri dari uji normalitas data, uji autokorelasi, uji multikolinearitas dan uji heterokedastisitas. Selanjutnya dilakukan pengujian hipotesis uji $\mathrm{F}$ dan uji t. Hasil pengujian menunjukkan hasil bahwa current ratio, net profit margin dan price earning share diperoleh nilai sebesar 0,097 artinya secara simultan tidak terdapat pengaruh signifikan terhadap variabel independen terhadap variabel dependen. Hasil uji t untuk variabel current ratio diperoleh nilai sebesar 0,962 $>0,05$, variabel net profit margin diperoleh nilai sebesar 0,223 $>0,05$ artinya CR dan NPM tidak berpengaruh signifikan terhadap pengembalian saham. Variabel Price earning share diperoleh nilai sebesar $0,044>0,05$ artinya terdapat pengaruh signifikan terhadap pengembalian saham.
\end{abstract}

Kata Kunci : Current Ratio, Net Profit Margin, Price Earning Ratio dan Return Saham

\section{A. Pendahuluan}

Pasar modal merupakan mediator pertemuan pialang dan investor dalam memperjualbelikan surat berharga dan sarana yang paling efektif untuk para investor menanamankan modalnya (investasi) agar dapat memperoleh keuntungan di masa yang akan datang, membentuk portofolio (gabungan dari berbagai investasi) yang sesuai dengan risiko dan tingkat keuntungan yang diharapkan oleh para investor. Instrumen pasar modal terbagi atas dua kelompok besar yaitu instrument kepemilikan seperti saham dan instrumen hutang seperti obligasi perusahaan, 
obligasi langganan, obligasi yang dapat dikonversikan menjadi saham dan sebagainya. Perusahaan yang membutuhkan dana menawarkan surat berharga dengan cara listing terlebih dahulu pada badan otoritas di pasar modal sebagai emiten.

Perkembangan aktivitas pasar modal yang pesat menuntut adanya informasi yang dapat diandalkan oleh pihak-pihak yang terlibat dalam pasar modal. Investor punya kendali yang tinggi terhadap aktivitas dan pertimbangan investasinya di pasar modal, perasaan aman merupakan syarat penting di antara syarat-syarat lain yang harus dipenuhi bagi investasinya tersebut. Untuk memenuhi hal tersebut, diperlukan informasi yang jelas, wajar dan tepat waktu sangat dibutuhkan keberadaanya.

Bursa Efek Indonesia (BEl) adalah wadah tempat investor merupakan salah satu bursa efek yang cepat perkembangannya sehingga menjadi alternatif yang disukai perusahaan untuk mencari dana dari para investor, perkembangan bursa efek dapat dilihat dengan banyaknya anggota bursa dan perubahan harga-harga saham yang diperdagangkan. Perubahan harga saham menunjukan tentang gairah dan kelesuan aktivitas pasar modal serta pemodal dalam melakukan transaksi jual beli saham.

Motivasi atau tujuan para investor untuk melakukan investasi di pasar modal tidak selalu sama. Bagi investor yang mempunyai tujuan untuk keuntungan jangka pendek, pada umumnya mereka menginginkan bagian dari keuntungan yang cepat yaitu berupa capital gain (variabel penelitian penulis) dengan cara membeli saham atau sekuritas lain pada saat harganya murah dan menjualnya pada saat harga saham meningkat. Sedangkan bagi investor yang ingin mendapatkan keuntungan jangka panjang berupa keinginan untuk memperoleh proporsi kepemilikan di perusahaan, pada umunya mereka kurang menangapi terjadinya fluktuasi harga saham.

Faktor-faktor yang mempengaruhi naik turunnya harga saham yaitu faktor mikro perusahaan dan faktor makro ekonomi. Faktor mikro (internal perusahaan) yang mempengaruhi harga saham antara lain : tingkat keuntungan yang diperoleh perusahaan, tingkat risiko yang dihadapi dan kinerja perusahaan tersebut. Sedangkan faktor makro (eksternal perusahaan) adalah tingkat inflasi, nilai tukar atau kurs rupiah, keadaan perekonomian dan kondisi sosial politik negara yang bersangkutan.

Harga saham mencerminkan nilai perusahaan dimata masyarakat. Apabila harga saham pada suatu perusahaan tinggi maka nilai perusahaan dimata masyarakat juga baik sebaliknya jika harga saham suatu perusahaan rendah maka nilai perusahaan di mata masyarakat juga kurang baik. Dari fluktuasi harga saham tersebut maka bagi para investor yang cermat melihat peluang dan mengikuti dengan seksama setiap perubahan, maka tentu para investor akan dapat memperoleh pengembalian berupa capital gain dari fluktuasi harga saham tersebut.

Informasi tentang kinerja perusahaan merupakan salah satu informasi yang penting dan salah satu jenis informasi yang menjadi pertimbangan investor dalam mengambil keputusan investasinya. Kinerja keuangan salah satunya dapat dinilai dari perhitungan rasio keuangan pada perusahaan tersebut. Untuk mengetahui tingkat likuiditas perusahaan, kemampuan perusahaan dalam menghasilkan laba dan melihat kinerja serta prospeknya dimasa akan datang, dan kesemuanya itu dapat dianalisis dengan mengunakan Rasio Likuiditas, Rasio Profitabilitas dan Rasio Nilai Pasar. Investor dapat mengetahui perusahaan yang mereka beli sahamnya mempunyai tingkat likuiditas yang tinggi. Perusahaan mempunyai cukup dana untuk 
memenuhi kewajiban-kewajiban jangka pendeknya. Hal ini memberikan rasa aman bagi para investor dalam menginvestasikan dananya, dan dapat ditunjukkan dengan mengunakan Current Ratio (CR).

Investor dapat mengetahui saham dari perusahaan yang akan dipilih untuk investasi, mempunyai kemampuan yang baik dalam menghasilkan keuntungan dari dana yang ditanamkan dalam keseluruhan aset. Keuntungan menjadi daya tarik utama bagi investor dalam melakukan investasi. Hal ini tercermin dalam Net Profit Margin (NPM). Price Earning Ratio (PER) berguna bagi investor untuk menunjukkan kinerja perusahaan di masa lalu dan prospeknya dimasa yang akan datang. Rasio ini juga menggambarkan situasi/keadaan prestasi perusahaan di pasar modal. PER yang tinggi menunjukkan ekspektasi investor tentang prestasi perusahaan di masa akan datang cukup tinggi.

Pemilihan subsektor otomotif dan komponen menjadi objek penelitian karena fluktuatifnya stabilitas perekonomian yang diiringi dengan produksi mobil harga menengah ke bawah yang diiringi dengan kemampuan konsumen membeli mobil yang tinggi. Perusahaan di sektor industri otomotif dan komponen diprediksi akan menunjukkan pertumbuhan yang positif seiring dengan disetujuinya program mobil murah dan rendah emisi oleh para produsen mobil kepada pemerintah. Kondisi di atas tentunya akan diiringi dengan kebutuhan akan komponen atau sparepart untuk otomotif juga mengalami pertumbuhan yang positif. Peningkatan pertumbuhan industri sektor otomotif dan komponen ini, maka akan menarik minat para investor untuk menanamkan modalnya pada industri ini. Masih menjadi suatu pertanyaan apakah meningkatnya pertumbuhan industri ini akan membuat pengembalian saham yang di dapat juga akan meningkat? Karena penanaman modal yang besar akan berdampak pada kegiatan operasional perusahaan untuk memproduksi produk juga akan semakin besar, yang kemudian berdampak pula atas profit yang dihasilkan.

Kondisi di lapangan meskipun profit yang tinggi tidak menjamin bahwa harga saham perusahaan juga akan mengalami peningkatan, hal ini dikarenakan untuk perusahaan yang sedang mengalami pertumbuhan pesat cenderung akan melakukan ekspansi atau investasi untuk mengembangkan usaha, sehingga memerlukan dana yang lebih besar dalam bentuk hutang dari pihak luar, hutang yang besar di pandang investor suatu hal yang negatif (risiko tinggi) untuk investasi, dan akan mempengaruhi fluktuatifnya harga saham yang membentuk pengembalian saham yang didapat dari investasinya.

Penelitian untuk memperkuat atau memperlemah penelitian terdahulu yang dilakukan Farkhan dan Ika (2013) berjudul Pengaruh Rasio Keuangan Terhadap Pengembalian Saham Perusahaan Manufaktur di Bursa Efek Indonesia,

\section{B. Rumusah Masalah}

Berdasarkan latar belakang penelitian di atas, maka didapatkan rumusan masalah sebagai berikut :

1. Bagaimana pengaruh Current Ratio, Net Profit Margin dan Price Earning Ratio secara simultan terhadap Pengembalian Saham Subsektor Otomotif dan Komponen di BEI?

2. Bagaimana pengaruh Current Ratio, Net Profit Margin dan Price Earning Ratio secara parsial terhadap Pengembalian Saham Subsektor Otomotif dan Komponen di BEl? 


\section{Kajian Pustaka}

1) Saham

Menurut Kasmir (2010:205), saham merupakan tanda kepemilikan perusahaan atas nama saham yang dibelinya. Menurut Susilo (2009:27), saham dapat didefinisikan sebagai tanda penyertaan modal seseorang atau pihak (badan usaha) dalam suatu perusahaan atau Perseroan Terbatas.

Menurut Sunariyah (2011:125), saham adalah surat berharga sebagai bukti penyertaan atau pemilikan individu maupun institusi yang dikeluarkan oleh sebuah perusahaan berbentuk Perseroan Terbatas. Saham adalah surat berharga sebagai bukti penyertaan atau pemilikan individu maupun institusi yang dikeluarkan oleh sebuah perusahaan yang berbentuk Perseroan Terbatas. Wujud saham adalah selembar kertas yang menerangkan bahwa pemilik kertas tersebut adalah pemilik perusahaan yag menerbitkan surat berharga tersebut (Sunariyah, 2011:49). Porsi kepemilikan ditentukan oleh seberapa besar penyertaan yang ditanamkan di perusahaan tersebut. Menurut Susilo (2009:70), ada dua macam bentuk saham yaitu;

a) Saham biasa (common stock), surat berharga yang memberikan penghasilan tidak tetap (tergantung kinerja dan kebijakan perusahaan), memiliki hak suara dalam Rapat Umum Pemegang Saham (RUPS). Kelebihan saham biasa adalah adanya hak suara (one share one vote) sehingga sering dipakai sebagai alat untuk menguasai perusahaan.

b) Saham preferen (preferred stock), merupakan saham yang memberikan penghasilan berupa dividen dalam jumlah yang tetap (\% tertentu dari nilai nominal), diberikan secara periodik, bersifat kumulatif dan di dahulukan. Pemegang saham preferen tidak memiliki hak suara dalam Rapat Umum Pemegang Saham (RUPS).

Menurut Sunariyah (2011:126), hak-hak yang dimiliki pemegang saham biasa adalah:

a) Memiliki hak suara dalam Rapat Umum Pemegang Saham (RUPS)

b) Hak atas laba bersih perusahaan sebagai hasil atas dana yang di investasikan. Hak atas laba dibagikan kepada seluruh pemegang saham berdasarkan jumlah lembar saham yang dikuasainya.

c) Hak terlebih dahulu untk membeli saham baru pada perusahaan yang bersangkutan sebelum dibeli investor baru.

d) Pada saat likuidasi pemegang saham biasa memiliki hak terakhir dalam hal pembagian kekayaan perusahaan.

Menurut Sunariyah (2011:131), hak-hak yang dimiliki pemegang saham preferen adalah:

a) Mempunyai dividen yang ditentukan dan disetujui oleh kedua belah pihak yaitu pemegang saham dan manajemen.

b) Dalam hal pembagian dividen, pemegang saham preferen mempunyai hak untuk menerima dividen terlebih dahulu sebelum pemegang saham biasa dibayarkan.

c) Pada kasus likuidasi, pemegang saham preferen mempuyai hak klaim terlebih dahulu sebelum pemegang saham biasa.

d) Pemegang saham preferen tidak mempunyai hak suara (voting). 


\section{2) Pengembalian Saham}

Sjahrial (2010:69), menyatakan pengembalian merupakan hasil yang diperoleh dari investasi. Menurut Fahmi (2013:189), pengembalian adalah keuntungan yang diperoleh oleh perusahaan, individu dan institusi dari hasil kebijakan investasi yang dilakukannya. Pengembalian terdiri dari dua, pengembalian realisasi (realized pengembalian) yaitu pengembalian yang telah terjadi, pengembalian yang terealisasi dihitung berdasarkan data historis. Pengembalian yang terealisasi penting karena digunakan sebagai salah satu pengukur kinerja dari perusahaan. Pengembalian ekspektasi yang belum terjadi tetapi diharapkan akan terjadi dimasa yang akan datang. Pengembalian yang diperoleh pemodal dengan membeli atau memiliki saham berupa dividend dan capital gain.

Dividend yaitu pembagian keuntungan yang diberikan perusahaan penerbit saham tersebut atas keuntungan yang dihasilkan perusahaan (Sunariyah, 2011:49). Dividen diberikan setelah mendapat persetujuan dari pemegang saham dalam rapat umum pemegang saham (RUPS). Jika seorang pemodal ingin mendapatkan dividen, maka pemodal tersebut harus memagang saham tersebut dalam kurun waktu yang relatif lama yaitu hingga kepemilikan saham tersebut berada dalam periode di mana diakui sebagai pemegang saham yang berhak mendapatkan dividen. Umumnya dividen merupakan salah satu daya tarik bagi pemegang saham dengan orientasi jangka panjang. Istilah lain dalam saham yaitu capital gain, merupakan selisih antara harga beli dengan harga jual. Capital gain terbentuk dengan adanya aktivitas perdagangan saham di pasar sekunder (Sunariyah, 2011:49). Umumnya pemodal dengan orientasi jangka pendek mengejar keuntungan melalui capital gain. Saham memungkinkan pemodal untuk mendapatkan pengembalian berupa (capital gain) jika harga saham sekarang $\left(\mathrm{P}_{\mathrm{t}}\right)$ lebih tinggi dari harga saham periode sebelumnya $\left(\mathrm{P}_{\mathrm{t}-1}\right)$. Dan apabila terjadi kebalikannya disebut capital loss.

Sjahrial (2010:70), Secara matematis formulasi pengembalian saham dapat dirumuskan sebagai berikut : $\boldsymbol{R}_{\boldsymbol{t}}=\frac{\boldsymbol{P}_{\boldsymbol{t}}-\boldsymbol{P}_{t-1}}{\boldsymbol{P}_{t-1}} \boldsymbol{x} \mathbf{1 0 0} \%$

\section{3) Rasio Keuangan}

Harahap (2010:297), menyatakan rasio keuangan adalah angka yang diperoleh dari hasil perbandingan dari satu pos laporan keuangan dengan pos lainnya yang mempunyai hubungan relevan dan signifikan (berarti). Menurut Kasmir (2012:104), rasio keuangan merupakan kegiatan membandingkan angka-angka yang ada dalam laporan keuangan dengan cara membagi satu angka dengan angka lainya. Perbandingan dapat dilakukan antara satu komponen dengan komponen lainya dalam satu laporan keuangan atau antar komponen yang ada diantara laporan keuangan. Hasil rasio keuangan ini digunakan untuk menilai kinerja manajemen dalam suatu periode.

Bagi manajer finansial dengan menghitung rasio-rasio keuangan tertentu akan memperoleh suatu informasi tentang kekuatan dan kelemahan yang dihadapi oleh perusahaan dalam bidang finansial, sehingga dapat membuat keputusan penting bagi perusahaaan untuk masa yang akan datang. Sedangkan bagi investor, atau calon investor atau calon pembeli saham, laporan keuangan merupakan bahan pertimbangan menguntungkan membeli saham perusahaan yang bersangkutan atau tidak. Harahap (2010:301), menyatakan rasio keuangan yang sering digunakan adalah sebagai berikut :

1. Rasio likuiditas yaitu rasio yang mengambarkan kemampuan perusahaan untuk 
menyelesaikan kewajiban jangka pendeknya.

2. Rasio solvabilitas yaitu rasio yang mengambarkan kemampuan perusahaan dalam membayar kewajiban jangka panjangnya atau kewajiban-kewajiban apabila perusahaan dilikuidasi.

3. Rasio profitabilitas/rentabilitas yaitu rasio yang mengambarkan kemampuan perusahaan dalam mendapatkan laba.

4. Rasio leverage yaitu rasio yang mengambarkan hubungan antara utang perusahaan terhadap modal maupun aset.

5. Rasio aktivitas yaitu rasio yang mengambarkan aktivitas yang dilakukan perusahaan dalam menjalankan operasinya baik dalam kegiatan penjualan, pembelian dan kegiatan lainnya.

6. Rasio pertumbuhan yaitu rasio yang mengambarkan persentasi pertumbuhan pos-pos perusahaan dari tahun ke tahun.

7. Rasio nilai Pasar (market based) yaitu rasio yang lazim dan khusus dipergunakan di pasar modal yang mengambarkan situasi/keadaan prestasi perusahaan di pasar modal.

8. Rasio Produktivitas yaitu rasio yang menunjukkan tingkat produktivitas dari unit atau kegiatan yang dinilai.

Dalam penelitian ini akan digunakan rasio likuiditas (Current Ratio), Profitabilitas (Net Profit Margin), dan rasio nilai pasar (Price Earning Ratio) :

\section{a. Rasio Likuiditas}

Kasmir (2012:129), Rasio likuiditas (liquidity ratio) adalah rasio yang menggambarkan kemampuan suatu perusahaan dalam memenuhi kewajiban jangka pendek. Artinya jika kewajiban jangka pendek jatuh tempo maka perusahaan akan mampu membayar atau memenuhinya dilihat dari kemampuan aset lancarnya. Untuk mengukur kemampuan likuiditas perusahaan salah satunya tercermin dari rasio lancar (current ratio) dan digunakan peneliti dalam penelitian ini. Kasmir (2010:134), rasio lancar (current ratio) merupakan rasio untuk mengukur kemampuan perusahaan dalam membayar kewajiban jangka pendek atau utang yang segera jatuh tempo dengan menggunakan aset lancar. Sehingga secara matematis Current Ratio (CR) dapat dirumuskan sebagai berikut:

$$
\text { Rasio Lancar }=\frac{\text { Aset Lancar }}{\text { Kewajiban Lancar }} \times 100 \%
$$

Aset lancar (current ratio) meliputi kas, piutang usahan, dan persediaan. Kewajiban lancar (current liabilities) terdiri atas utang usaha, wasel tagih jangka pendek, utang jatuh tempo yang kurang dari satu tahun, akrual pajak, dan bebanbeban akrual lainya.

\section{b. Rasio Profitabilitas}

Kasmir (2012:196), menyatakan rasio profitabilitas merupakan rasio untuk menilai kemampuan perusahaan dalam mencari keuntungan. Rasio ini juga memberikan ukuran tingkat efektifitas manajemen suatu perusahaan. Hal ini ditunjukan oleh laba yang dihasilkan dari penjualan dan pendapatan investasi. Untuk mengukur kemampuan profitabilitas perusahaan salah satunya dapat ditunjukkan dari rasio margin laba bersih atau Net Profit Margin (NPM) dan digunakan peneliti dalam penelitian ini. Kasmir (2010:135), margin laba bersih atau Net Profit Margin 
merupakan ukuran keuntungan dengan membandingkan antara laba setelah bunga dan pajak dibandingkan dengan penjualan. Sehingga secara matematis Net Profit Margin (NPM) dapat dirumuskan sebagai berikut:

$$
\text { Margin Laba Bersih }=\frac{\text { Laba Setelah Bunga dan Pajak }}{\text { Penjualan Bersih }} \times 100 \%
$$

\section{c. Rasio Nilai Pasar}

Menurut Fahmi (2012:70), rasio nilai pasar yaitu rasio yang menggambarkan kondisi yang terjadi di pasar. Rasio ini juga sering dipakai untuk melihat bagaimana kondisi perolehan keuntungan yang potensial dari suatu perusahaan jika menempatkan dana di perusahaan tersebut terutama untuk masa yang akan datang. Untuk mengukur kemampuan nilai pasar perusahaan salah satunya dapat dilihat dari rasio Price Earning Ratio dan digunakan peneliti dalam penelitian ini.

Menurut Harahap (2010:311), Price Earning Ratio menunjukkan perbandingan antara harga saham di pasar atau harga perdana yang ditawarkan dibandingkan dengan pendapatan yang diterima. Secara matematis $P E R$ dapat dirumuskan sebagai berikut :

$$
\text { Rasio Harga Laba }=\frac{\text { Harga per Saham }}{\text { Laba Per Saham }} \times 100 \%
$$

Rasio ini menunjukan seberapa jauh sebuah perusahaan mampu menciptakan nilai perusahaan. PER yang tinggi menunjukan ekspektasi investor tentang prestasi perusahaan dimasa yang akan datang cukup tinggi.

\section{4) Hipotesis Penelitian:}

H1: Current Ratio (CR) berpengaruh signifikan terhadap Pengembalian Saham.

H2: Net Profit Margin (NPM) berpengaruh signifikan terhadap Pengembalian Saham.

H3: Price Earning Ratio (PER) terhadap Pengembalian Saham.

H4: Pengaruh Current Ratio (CR), Net Profit Margin (NPM), dan Price Earning Ratio (PER) terhadap Pengembalian Saham.

\section{Metode Penelitian}

Pada tabel berikut ini akan dijelaskan secara terperinci defenisi variabel operasional dalam penelitian ini berikut dengan indikator-indikatornya.

Tabel 1. Defenisi Operasional Variabel

\begin{tabular}{|c|l|c|c|}
\hline Variabel & \multicolumn{1}{|c|}{ Definsi } & Indikator & Skala \\
\hline $\begin{array}{c}\text { Current } \\
\text { Ratio } \\
\left(\mathrm{X}_{1}\right)\end{array}$ & $\begin{array}{l}\text { Rasio yang mengukur } \\
\text { kemampuan likuiditas untuk } \\
\text { membayar utang lancar } \\
\text { segera dengan asset lancar. } \\
\text { Harahap (2010:301) }\end{array}$ & CR $\begin{array}{c}\text { Aset Lancar } \\
\text { Hutang Lancar }\end{array} 100 \%$ & Rasio \\
\hline $\begin{array}{c}\text { Net Profit } \\
\text { Margin } \\
\left(\mathrm{X}_{2}\right)\end{array}$ & $\begin{array}{l}\text { merupakan keuntungan } \\
\text { dengan membandingkan } \\
\text { antara laba bersih setelah } \\
\text { pajak dibandingkan dengan } \\
\text { penjualan. Kasmir (2010:200) }\end{array}$ & NPM $=\frac{\text { EAIT }}{\text { SALES }} \times 100 \%$ & Rasio \\
\hline Price & PER rasio harga per saham & PER $=\frac{\text { Price Per Share }}{\text { Earning per Share }} 100 \%$ & Rasio \\
\hline
\end{tabular}




\begin{tabular}{|c|l|l|l|}
\hline $\begin{array}{c}\text { Earning } \\
\text { Ratio } \\
\left(\mathrm{X}_{3}\right)\end{array}$ & $\begin{array}{l}\text { terhadap laba per saham. } \\
\text { Harahap (2010:311) }\end{array}$ & & \\
\hline $\begin{array}{c}\text { Pengembali } \\
\text { an Saham } \\
(\mathrm{Y})\end{array}$ & $\begin{array}{l}\text { Pengembalian merupakan } \\
\text { hasil yang diperoleh dari } \\
\text { investasi. hasil investasi } \\
\text { berupa capital gain(loss) } \\
\text { yaitu selisih antara harga } \\
\text { saham periode saat ini } \\
\text { dengan harga saham pada } \\
\text { periode sebelumnya. Sjahrial } \\
\text { (2010:70) }\end{array}$ & Rasio \\
\hline
\end{tabular}

\section{E. Populasi dan Sampel}

Populasi dalam penelitian ini adalah seluruh perusahaan yang bergerak di sektor otomotif dan komponen yang telah terdaftar di Bursa Efek Indonesia pada tahun 2010 sampai dengan 2013 yang berjumlah 12 (dua belas) perusahaan. Penarikan sampel dengan purposive sampling. Kriteria sampel Pengembalian saham tidak mengalami capital loss lebih dari lima puluh persen (>50\%) selama periode pengamatan, maka terseleksi 8 (delapan) perusahaan. Kedelapan perusahaan tersebut dapat dilihat pada tabel berikut :

Tabel 2. Sampel Penelitian

\begin{tabular}{|c|c|l|l|}
\hline No & $\begin{array}{c}\text { Kode } \\
\text { Perusahaan }\end{array}$ & \multicolumn{1}{|c|}{ Tanggal Listing } & \multicolumn{1}{c|}{ Nama Perusahaan } \\
\hline 1 & GDYR & 22 Desember 1980 & Goodyear Indonesia Tbk \\
\hline 2 & LPIN & 05 Februari 1990 & Multi Prima Sejahtera Tbk \\
\hline 3 & ASII & 04 April 1990 & Astra International Tbk \\
\hline 4 & GJTL & 08 Mei 1990 & Gajah Tunggal Tbk \\
\hline 5 & PRAS & 12 Juli 1990 & Prima Alloy Steel Universal Tbk \\
\hline 6 & BRAM & 05 September 1990 & Indo Kordsa Tbk \\
\hline 7 & IMAS & 15 November1993 & Indomobil Sukses Internasional Tbk \\
\hline 8 & SMSM & 09 September 1996 & Selamat Sempurna Tbk \\
\hline
\end{tabular}

Sumber : www.idx.co.id

\section{F. Teknik Analisis Data}

1) Uji Regresi Linier Sederhana

Pengujian ini dilakukan untuk mengetahui pengaruh variabel bebas terhadap variabel terikat secara parsial. Menurut Supardi (2013:229), Regresi linier sederhana yaitu regresi linier dengan satu variabel predictor (bebas).

berikut: $Y=\alpha+\beta_{1} X_{1}+\beta_{2} X_{2}+\beta_{3} X_{3}+e$

2) Uji Hipotesis

Uji hipotesis dalam penelitian ini mengunakan alat analisis statistik koefesien determinasi, uji t dan uji F. Perhitungan statistik dikatakan signifikan apabila nilai uji yang dikehendaki berada dalam daerah kritis (daerah di mana $\mathrm{H}_{0}$ ditolak). $\mathrm{H}_{0}$ yang menyatakan bahwa variabel independen tidak berpengaruh secara parsial maupun 
simultan terhadap variabel dependen. Tidak signifikan apabila nilai uji statistiknya berada dalam daerah di mana $\mathrm{H}_{\mathrm{a}}$ diterima.

\section{G. Hasil Penelitian}

a. Current Ratio

Data Current Ratio perusahaan otomotif dan komponen dapat dilihat tabel berikut ini:

Tabel 3. Current Ratio pada Perusahaan otomotif dan komponen

\begin{tabular}{|c|c|c|c|c|c|c|}
\hline \multirow{2}{*}{ No } & \multirow{2}{*}{$\begin{array}{c}\text { Kode } \\
\text { Emiten }\end{array}$} & $\mathbf{2 0 1 0}$ & $\mathbf{2 0 1 1}$ & $\mathbf{2 0 1 2}$ & $\mathbf{2 0 1 3}$ & $\begin{array}{c}\text { Rata- } \\
\text { rata }\end{array}$ \\
\cline { 3 - 7 } & ASII & 126 & 136 & 139 & 124 & 131,25 \\
\hline 1 & BRAM & 402 & 279 & 213 & 157 & 262,75 \\
\hline 2 & GDYR & 86 & 85 & 89 & 94 & 88,50 \\
\hline 3 & GJTL & 176 & 175 & 172 & 230 & 188,25 \\
\hline 4 & LPIN & 252 & 293 & 290 & 248 & 270,75 \\
\hline 5 & MASA & 67 & 48 & 139 & 157 & 102,75 \\
\hline 6 & PRAS & 135 & 114 & 111 & 103 & 115,75 \\
\hline 7 & SMSM & 217 & 240 & 205 & 210 & 218 \\
\hline 8 & Rata-rata & 182,62 & 171,25 & 169,75 & 165,38 & \\
\hline \multicolumn{7}{|c|}{402} \\
\hline
\end{tabular}

Sumber: Data sekunder yang diolah, tahun 2015

Berdasarkan tabel 3 diperoleh gambaran bahwa rata-rata current ratio perusahaan-perusahaan otomotif dan komponen setelah data ditranformasi selama periode penelitian terus mengalami penurunan. Pada tahun 2010 tingkat CR sebesar $5,02 \%$ dan pada tahun 2011 menurun menjadi 4,99\% dan kembali naik pada tahun 2012 menjadi 5,07\% kemudian pada tahun 2013 tetap mengalami penurunan nilai CR menjadi 5,05 g\%. Secara umum untuk tingkat CR paling tinggi diperoleh oleh PT Indo Kordsa Tbk pada tahun 2010 dengan nilai 6,00\% dan tingkat CR paling rendah dengan nilai 3,87\% diperoleh PT. Multi Strada Arah Sarana Tbk pada tahun 2011. Begitu pula secara rata-rata tingkat CR paling tinggi diperoleh PT Multi Prima Sejatera Tbk dengan perolehan rata-rata CR sebesar $5,57 \%$ dan paling rendah ratarata CR diperoleh PT Goodyear Indonesia Tbk yaitu 4,48\%.

\section{b. Net Profit Margin}

Data NPM perusahaan otomotif dan komponen yang terdaftar di BEl tahun 2010-2013 dapat dilihat tabel berikut ini:

Tabel 4. Net Profit Margin pada Perusahaan Otomotif dan komponen

\begin{tabular}{|c|c|c|c|c|c|c|}
\hline \multirow{2}{*}{ No } & \multirow{2}{*}{$\begin{array}{l}\text { Kode } \\
\text { Emiten }\end{array}$} & \multicolumn{4}{|c|}{ Net Profit Margin } & \multirow{2}{*}{$\begin{array}{l}\text { Rata- } \\
\text { rata }\end{array}$} \\
\hline & & 2010 & 2011 & 2012 & 2013 & \\
\hline 1 & ASII & 13 & 13 & 12 & 11 & 12,25 \\
\hline 2 & BRAM & 8 & 4 & 13 & 2 & 6,75 \\
\hline 3 & GDYR & 4 & 2 & 3 & 3 & 3,00 \\
\hline 4 & GJTL & 8 & 6 & 9 & 1 & 6,25 \\
\hline 5 & LPIN & 24 & 18 & 24 & 11 & 19,25 \\
\hline 6 & MASA & 8 & 5 & 1 & 1 & 3,75 \\
\hline 7 & PRAS & 1 & 2 & 13 & 27 & 10,75 \\
\hline 8 & SMSM & 11 & 12 & 12 & 13 & 12,00 \\
\hline \multicolumn{2}{|r|}{ Rata-rata } & 9,63 & 7,75 & 10,88 & 8,63 & \\
\hline \multirow{2}{*}{\multicolumn{2}{|c|}{$\begin{array}{c}\text { Max } \\
\text { Min }\end{array}$}} & \multicolumn{4}{|c|}{27} & 19,25 \\
\hline & & \multicolumn{4}{|c|}{1} & 3,00 \\
\hline
\end{tabular}

Sumber: Data sekunder yang diolah, tahun 2015 
Berdasarkan tabel 4 diperoleh gambaran bahwa rata-rata net profit margin perusahaan-perusahaan otomotif dan komponen selama periode penelitian terus mengalami peningkatan. Pada tahun 2010 tingkat NPM sebesar 1,97\% dan pada tahun 2011 menurun menjadi $1,76 \%$ dan kembali meningkat pada tahun 2012 menjadi 2,07\% kemudian pada tahun 2013 tetap mengalami penurunan nilai NPM menjadi $1,56 \%$. Secara umum untuk tingkat NPM paling tinggi diperoleh oleh PT Multi Prima Sejahtera Tbk pada tahun 2011 dengan nilai 3,30\% dan tingkat NPM paling rendah dengan nilai $0,00 \%$ diperoleh PT Goodyear Indonesia Tbk, PT Multistrada Arah Sarana Tbk dan PT Prima Alloy Steel Universal Tbk. Begitu pula secara rata-rata tingkat NPM paling tinggi diperoleh PT Multi Prima Sejahtera Tbk dengan perolehan rata-rata NPM sebesar $2,91 \%$ dan paling rendah rata-rata NPM diperoleh PT Goodyear Indonesia Tbk yaitu 0,92\%.

\section{c. Price Earning Ratio}

Data PER perusahaan otomotif dan komponen yang terdaftar di BEl tahun 2010-2013 dapat dilihat tabel berikut ini:

\begin{tabular}{|c|c|c|c|c|c|c|}
\hline \multirow{2}{*}{ No } & \multirow{2}{*}{$\begin{array}{c}\text { Kode } \\
\text { Emiten }\end{array}$} & \multicolumn{4}{|c|}{ Price Earning Ratio } & \multirow{2}{*}{$\begin{array}{l}\text { Rata- } \\
\text { rata }\end{array}$} \\
\hline & & 2010 & 2011 & 2012 & 2013 & \\
\hline 1 & ASII & 15,37 & 14,03 & 13,70 & 15,33 & 14,61 \\
\hline 2 & BRAM & 8,05 & 17,60 & 5,69 & 20,40 & 12,91 \\
\hline 3 & GDYR & 7,70 & 10,52 & 7,81 & 11,46 & 9,37 \\
\hline 4 & GJTL & 9,65 & 11,05 & 7,14 & 21,35 & 12,30 \\
\hline 5 & LPIN & 4,70 & 4,13 & 9,79 & 8,04 & 6,71 \\
\hline 6 & MASA & 11,47 & 21,44 & 60,12 & 18,38 & 27,85 \\
\hline 7 & PRAS & 17,54 & 17,13 & 3,62 & 16,22 & 13,63 \\
\hline 8 & SMSM & 10,24 & 8,93 & 13,54 & 47,49 & 19,95 \\
\hline \multicolumn{2}{|r|}{ Rata-rata } & 10,59 & 13,11 & 15,18 & 19,83 & \\
\hline \multirow{2}{*}{\multicolumn{2}{|c|}{$\begin{array}{c}\text { Max } \\
\text { Min }\end{array}$}} & \multicolumn{4}{|c|}{60,12} & 27,85 \\
\hline & & \multicolumn{4}{|c|}{4,13} & 6,71 \\
\hline
\end{tabular}

Sumber: Data sekunder yang diolah, tahun 2015

Berdasarkan table 5 diperoleh gambaran bahwa rata-rata price earning ratio perusahaan-perusahaan otomotif dan komponen selama periode penelitian tidak terlalu mengalami perubahan. Pada tahun 2010 tingkat PER sebesar 2,28\% dan naik pada tahun 2011 yaitu $2,46 \%$ dan pada tahun 2012 menjadi 2,32\% serta pada tahun 2013 yaitu 2,86\%. Secara umum untuk tingkat PER paling tinggi diperoleh oleh PT Multistrada Arah SaranaTbk pada tahun 2012 dengan nilai 4,10\% dan tingkat PER paling rendah dengan nilai $1,29 \%$ diperoleh PT Multi Prima Sejahtera Tbk pada tahun 2011. Begitu pula secara rata-rata tingkat PER paling tinggi diperoleh PT. Multi Prima Sejahtera Tbk dengan perolehan rata-rata PER sebesar 3,13\% dan paling rendah rata-rata PER diperoleh PT Multistrada Arah Sarana Tbk yaitu 1,84\%.

\section{d. Pengembalian Saham}

Data return saham perusahaan otomotif dan komponen yang terdaftar di BEI tahun 2010-2013 dapat dilihat tabel berikut ini: 
Tabel 6. Return Saham pada Perusahaan Otomotif dan komponen

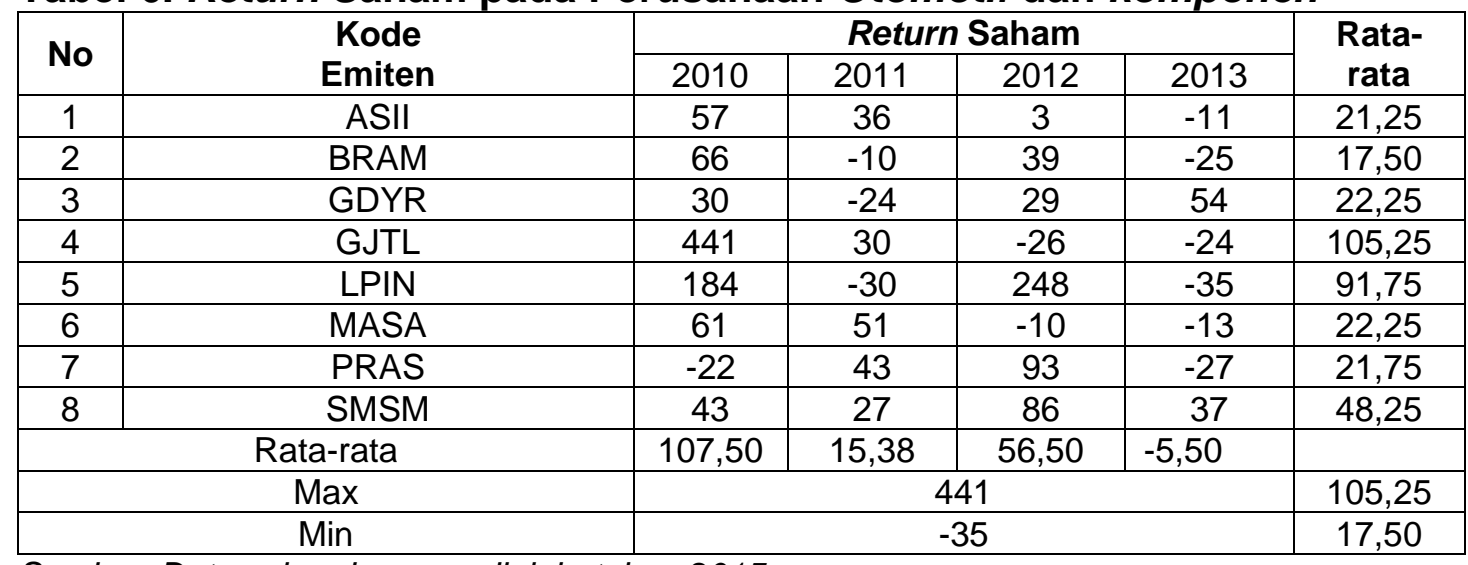

Sumber: Data sekunder yang diolah, tahun 2015

Bedasarkan tabel 6 diperoleh gambaran bahwa rata-rata return saham perusahaan-perusahaan otomotif dan komponen selama periode penelitian mengalami fluktuasi. Pada tahun 2010 tingkat return saham sebesar 4,24\% menurun pada tahun 2011 menjadi 3,36\% dan kembali naik pada tahun 2012 menjadi 3,77\% kemudian pada tahun 2013 mengalami penurunan nilai return saham menjadi 3,23\%. Rata-rata nilai return saham paling tinggi diperoleh oleh PT Gajah Tunggal Tbk dengan nilai $6,09 \%$. Sedangkan untuk tingkat rata-rata return saham paling rendah diperoleh oleh PT Indo Kordsa Tbk dengan nilai 1,10\%. Secara umum perolehan rata-rata return saham paling tinggi diperoleh $\mathrm{PT}$ Gajah Tunggal Tbk dengan nilai $4,42 \%$ pada tahun 2010 . Dan perolehan return saham paling rendah diperoleh oleh PT Multi Prima Sejahtera Tbk pada tahun 2013 dengan nilai 1,10\%.

\section{Regresi Linier Berganda}

Analisis regresi berganda digunakan untuk mengetahui bagaimana hubungan lima variabel, dalam hal ini variabel current ratio, net profit margin dan price earning ratio dengan return saham. Hal ini dapat diketahui dengan bentuk persamaan regresinya. Adapun hasil pengolahan data sebagai berikut :

Tabel 7. Nilai Regresi Berganda

\begin{tabular}{|l|l|c|}
\hline No & Keterangan & Nilai \\
\hline 1 & Constant & 4.127 \\
\hline 2 & Current Asset & 0.017 \\
\hline 3 & Net Profit Margin & 0.236 \\
\hline 4 & Price Earning Ratio & -0.426 \\
\hline 7 & Error & 0.90368 \\
\hline
\end{tabular}

Sumber: Data sekunder yang diolah 2015

Model analisis regresi berganda antara variabel $X$ terhadap $Y$ dapat diformulasikan dalam model persamaan sebagai berikut:

$$
Y=4.127-0.017 X_{1}+0.236 X_{2}-0.426 X_{3}+0.90368
$$

Dari hasil persamaan regresi berganda tersebut, masing-masing variabel bebas dapat diinterprestasikan pengaruhnya terhadap return saham sebagai berikut:

1) Nilai konstanta sebesar 4,127 hal ini menunjukkan bahwa meskipun tidak ada CR, NPM dan PER, maka return saham perusahaan akan tetap ada sebesar 4,127 . 
2) Current ratio $(\mathrm{CR})\left(\mathrm{X}_{1}\right)$ memiliki koefisien bertanda positif sebesar 0.017 , hal tersebut berarti apabila nilai koefisien regresi variabel lainya tetap (tidak berubah), maka perubahan $\mathrm{CR}$ sebesar $1 \%$ akan menaikan return saham sebesar 0,017 atau 1,7\%.

3) Net Profit Margin (NPM) $\left(\mathrm{X}_{2}\right)$ memiliki koefisien bertanda positif sebesar 0.236, hal tersebut berarti apabila nilai koefisien regresi variabel lainya tetap (tidak berubah), maka perubahan NPM sebesar $1 \%$ akan menaikan return saham sebesar 0.236 atau $23,6 \%$.

4) Price Earning Ratio (PER) $\left(\mathrm{X}_{3}\right)$ memiliki koefisien bertanda negatif sebesar 0,426 , hal tersebut berarti apabila nilai koefisien regresi variabel lainya tetap (tidak berubah), maka perubahan PER sebesar $1 \%$ akan menurunkan return saham sebesar 0.426 atau $42,6 \%$.

\section{Pengujian Hipotesis}

\section{Hasil Uji t (Parsial)}

Uji t ini digunakan utuk membuktikan apakah variabel independen (CR, NPM, dan PER) secara individu mempengaruhi variabel dependen (Pengembalian Saham). Hasil pengolahan data sebagai berikut :

Tabel 8. Hasil Uji Hipotesis t

\begin{tabular}{|l|c|c|c|}
\hline \multicolumn{1}{|c|}{ Variabel } & Signifikan & $\alpha=0,05$ & \multicolumn{1}{c|}{ Keterangan } \\
\hline current ratio & 0,962 & & $0,962>0,05=$ tidak Signifikan \\
Net Profit Margin & 0,223 & 0,05 & $0,223>0,05=$ tidak signifikan \\
Price Earning Ratio & 0,044 & & $0,044>0,05=$ signifikan \\
\hline
\end{tabular}

Sumber: Data sekunder yang diolah 2015

Berdasarkan tabel di atas, menunjukan bahwa nilai signifikan current asset sebesar 0,962 > 0,05 artinya tidak terdapat pengaruh signifikan CR terhadap pengembalian saham. Variabel Net Profit Margin sebesar 0,223 > 0,05 artinya tidak pengaruh signifikan NPM terhadap pengembalian saham. Variabel Price Earning Share 0,044 > 0,05 artinya terdapat pengaruh signifikan terhadap pengembalian saham.

\section{Hasil Uji F}

Pengujian hipotesis uji F digunakan untuk melihat apakah secara keseluruhan variabel independen mempunyai pengaruh yang signifikan terhadap variabel dependen. Hasil pengolahan data sebagai berikut :

Tabel 9. Hasil Uji F CR, NPM, dan PER terhadap Return Saham

\begin{tabular}{|l|c|c|l|}
\hline \multicolumn{1}{|c|}{ Variabel Signifikan } & $\alpha=0,05$ & \multicolumn{1}{|c|}{ Keterangan } \\
\hline $\begin{array}{l}\text { Current ratio,net profit } \\
\text { margin, perice earning } \\
\text { ratio, terhadap return } \\
\text { Saham }\end{array}$ & 0,097 & 0,05 & $\begin{array}{l}\text { Signifikan } \\
\text { Salidak }\end{array}$ \\
\hline
\end{tabular}

Sumber: Data sekunder yang diolah 2015

Hasil uji F menunjukan bahwa variabel independen current ratio,net profit margin, dan perice earning ratio mempunyai tingkat signifikansi yang lebih besar dari $0,05(0,097<0,05)$. Menunjukkan bahwa variabel independen rasio keuangan dengan proksi current ratio, net profit margin, dan perice earning ratio tidak 
berpengaruh secara simultan (bersama-sama) terhadap return saham perusahaan pada perusahaan bidang otomotif dan komponen yang terdaftar pada Bursa Efek Indonesia periode 2010-2013, berarti $\mathrm{H}_{0}$ ditolak, $\mathrm{H}_{a}$ diterima.

\section{H. Pembahasan}

Berdasarkan hasil penelitian yang telah dilakukan selama periode pengamatan (2010-2013) menunjukkan bahwa hasil pengujian dengan menggunakan variabel current ratio $(\mathrm{CR})$ sebagai proksi rasio likuiditas tidak berpengaruh signifikan terhadap pengembalian saham pada perusahaan bidang otomotif dan komponen yang terdaftar di BEl. Hasil tersebut menunjukkan bahwa $\mathrm{H}_{1}$ ditolak. Dengan kata lain dapat disimpulkan bahwa rasio likuiditas yang diproksi dengan menggunakan variabel current ratio $(\mathrm{CR})$ tidak berpengaruh secara signifikan terhadap pengembalian saham (Y). Hasil ini selaras dengan penelitian Farkhan dan Ika (2013) yang menyatakan bahwa CR tidak berpengaruh terhadap pengembalian saham.

Hasil ini mengindikasikan bahwa dari sudut likuiditas, informasi yang diberikan kurang menarik bagi pihak investor. Hal ini disebabkan oleh likuiditas hanya memberikan informasi yang berhubungan dengan kemampuan perusahaan dalam memenuhi kewajiban jangka pendeknya saja, tetapi tidak bisa memberikan sinyal positif bagi keterlanjutan investasi yang ditanamkan oleh investor

\section{Pengaruh Net Profit Margin Terhadap Return Saham}

Berdasarkan hasil penelitian yang telah dilakukan selama periode pengamatan (2010-2013) menunjukkan bahwa hasil pengujian dengan menggunakan variabel net profit margin (NPM) sebagai proksi rasio profitabilitas tidak berpengaruh signifikan terhadap pengembalian saham pada perusahaan bidang otomotif dan komponen yang terdaftar di BEl. Hasil tersebut menunjukkan bahwa $\mathrm{H}_{2}$ ditolak. Dengan kata lain dapat disimpulkan bahwa rasio profitabilitas yang diproksi dengan menggunakan variabel net profit margin (NPM) tidak berpengaruh secara signifikan terhadap pengembalian saham $(\mathrm{Y})$.

Hasil penelitian ini belum dapat menunjukkan bahwa NPM yang merupakan alat untuk mengukur kemampuan perusahaan dalam menghasilkan laba dilihat dari penjualannya, hal ini dikarenakan penjualan harus disesuaikan dengan biaya-biaya yang dikeluarkan sebelum barang atau produk itu terjual atau dapat dikatakan investor belum tertarik dengan ukuran profitabilitas ini. Hasil penelitian ini mengindikasikan belum adanya perhatian yang cukup besar dari para investor untuk melihat NPM.

\section{Pengaruh Price Earning Ratio Terhadap Return Saham}

Berdasarkan hasil penelitian yang telah dilakukan selama periode pengamatan (2010-2013) menunjukkan bahwa hasil pengujian dengan menggunakan variabel price earning ratio (PER) sebagai proksi rasio nilai pasar tidak berpengaruh signifikan terhadap pengembalian saham pada perusahaan bidang otomotif dan komponen yang terdaftar di BEl. Hasil tersebut menunjukkan bahwa $\mathrm{H}_{3}$ ditolak. Dengan kata lain dapat disimpulkan bahwa rasio nilai pasar yang diproksi dengan menggunakan variabel price earning ratio (PER) tidak berpengaruh secara signifikan terhadap pengembalian saham (Y). Hasil ini bertentangan dengan penelitian Farkhan dan Ika (2013) yang menyatakan bahwa PER berpengaruh terhadap pengembalian saham.

Fokus utama investor lebih kepada bagaimana tingkat kemampuan perusahaan dalam menghasilkan laba, karena tidak bisa ditutupi bahwa laba memberikan daya 
tarik yang paling besar untuk menilai suatu perusahaan, hal ini menyebabkan investor tidak tertarik untuk melihat rasio penilaian pasar.

Serta informasi yang disajikan memberikan gambaran bagaimana aset yang terdapat pada perusahaan dapat dikembalikan dari hasil aktivitasnya berupa pendapatan atau penjualan bersih pada perusahaan tersebut.

\section{Pengaruh CR, NPM, dan PER Terhadap Return Saham}

Berdasarkan hasil penelitian yang telah dilakukan selama periode pengamatan (2010-2013) menunjukkan bahwa hasil pengujian dengan menggunakan variabel current ratio $(\mathrm{CR})$, net profit margin (NPM), dan price earning ratio (PER) sebagai proksi rasio likuiditas, rasio profitabilitas, dan rasio nilai pasar tidak berpengaruh signifikan terhadap pengembalian saham pada perusahaan bidang otomotif dan komponen yang terdaftar di BEl. Hasil tersebut menunjukkan bahwa $\mathrm{H}_{4}$ ditolak. Dengan kata lain dapat disimpulkan bahwa rasio likuiditas, rasio profitabilitas, dan rasio nilai pasar yang diproksi dengan menggunakan variabel current ratio $(\mathrm{CR})$, net profit margin (NPM), dan price earning ratio (PER) tidak berpengaruh secara signifikan terhadap pengembalian saham (Y).

Dalam penelitian ini CR, NPM, dan PER tidak bisa dijadikan oleh para investor sebagai bahan pertimbangan untuk melakukan keputusan investasi. CR, NPM, dan PER belum cukup memberikan cerminan bagi para investor untuk melihat seberapa baik tingkat likuiditas perusahaan, kemampuan perusahaan dalam menghasilkan laba, dan seberapa baik kinerja perusahaan serta belum mampu menjelaskan seberapa besar ekspektasi pasar terhadap perusahaan, hal ini lebih dikeranakan variabel independen yang digunakan masih terlalu sedikit atau tidak menyeluruh dan hampir semua hasil perhitungan rasio keuangan masih jauh lebih rendah di bawah standar rata-rata industri.

\section{Kesimpulan}

1) Hasil pengujian tingkat signifikan (uji t) atau parsial menunjukan variabel Current Ratio (CR), dan Net Profit Margin (NPM), tidak memiliki pengaruh signifikan terhadap pengembalian saham sedangkan Price Earning Ratio (PER) memiliki pengaruh signifikan terhadap Pengembalian Saham.

2) Hasil uji statistik F (ANOVA) yang telah dilakukan dapat diambil kesimpulan bahwa variabel Independen (current ratio, net profit margin, dan price earning ratio) tidak memiliki pengaruh signifikan terhadap variabel dependen (pengembalian saham) pada perusahaan bidang otomotif dan komponen yang terdaftar di Bursa Efek Indonesia (BEl).

\section{J. Saran}

Penulis akan memberikan beberapa saran yang mungkin dapat berguna dan dijadikan bahan pertimbangan baik bagi investor, perusahaan, dan peneliti selanjutnya untuk masa yang akan datang.

1. Untuk investor disarankan dalam melakukan investasi supaya juga mempertimbangkan informasi-informasi ekonomi yang memerlukan analisis di luar dari analisis rasio keuangan, seperti analisis teknikal dan analisis capital asset pricing model (CAPM). Untuk memberikan informasi yang lebih baik dan variatif sebagai bahan pertimbangan melakukan keputusan investasi.

2. Untuk perusahaan penulis menyarankan agar perusahaan melakukan peningkatan rasio keuangan khususnya dalam pengelolaan aset, kewajiban 
perusahaan, dan lebih meningkatkan laba perusahaan sebagian besar rasio keuangan CR dan NPM masih jauh di bawah standar rata-rata industri. Masa akan datang bisa menghasilkan tingkat pengembalian yang lebih baik, hal tersebut perlu dilakukan agar bisa menarik investor untuk menanamkan modalnya pada perusahaan.

\section{DAFTAR PUSTAKA}

Fahmi, Irham. 2012. Analisis Kinerja Keuangan. Bandung : Alfabeta. . 2013. Pengatar Pasar Modal. Bandung: Alfabeta.

Farkhan dan Ika. 2013. Pengaruh Rasio Keuangan Terhadap Pengembalian Saham Perusahaan Manufaktur di Bursa Efek Indonesia, (online), (http:// jurnal.unimus.ac.id/index.php/added/article/view/article/view/729/783, diakses 10 April 2015.

Harahap, Sofyan Syafri. 2010. Analisis Kritis Atas Laporan Keuangan. Jakarta: Rajawali Pers.

Ikatan Akuntan Indonesia. 2013. PSAK No.1 Tahun 2013. Jakarta: IAI

Kasmir. 2012. Analisa laporan keuangan. Jakarta: Rajawali Pers. .2010. Pengantar Manajemen Keuangan. Jakarta: Kencana.

Priyatno, Dwi. 2014. SPSS Pengolahan Data Terpraktis.Yogyakarta: Andi

Sjahrial, Dermawan. 2010. Manajemen Keuangan. Jakarta: Mitra Wacana Media.

Sugiyono. 2013. Statitistika untuk Penelitian. Bandung: Alfabeta.

Supardi. 2013. Aplikasi Statistika dalam Penelitian. Edisi Revisi. Jakarta:Prima Ufuk Semesta.

Sunariyah. 2011. Pengantar Pengetahuan Pasar Modal. Yogyakarta: UPP STIM YKPN.

Widarjono, Agus. 2010. Analisa Statistika Multivariat Terapan. Yogyakarta: UPP STIM YKPN.

www.co.id. 2013. Bursa Efek Indonesia (BEI) 